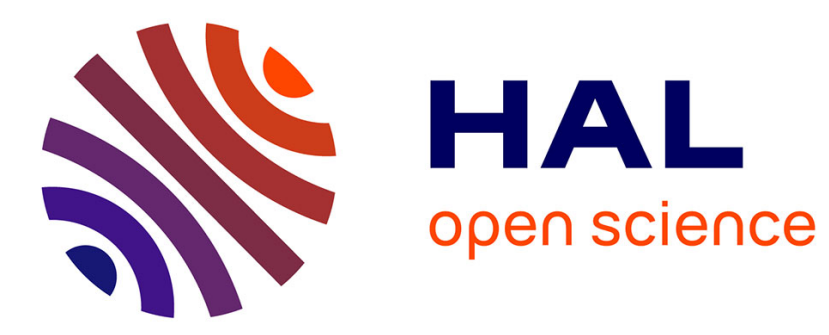

\title{
Fleur-de-lys abdominal body contouring surgery following massive weight loss
}

Yanis Berkane, François Saget, Silvia Gandolfi, Théodoros Chrelias, Eric

Watier, Nicolas Bertheuil

\section{- To cite this version:}

Yanis Berkane, François Saget, Silvia Gandolfi, Théodoros Chrelias, Eric Watier, et al.. Fleur-de-lys abdominal body contouring surgery following massive weight loss. Journal of Plastic, Reconstructive and Aesthetic Surgery, 2021, 74 (8), pp.1931-1971. 10.1016/j.bjps.2021.05.032 . hal-03283663

\section{HAL Id: hal-03283663 \\ https://hal.science/hal-03283663}

Submitted on 16 Jul 2021

HAL is a multi-disciplinary open access archive for the deposit and dissemination of scientific research documents, whether they are published or not. The documents may come from teaching and research institutions in France or abroad, or from public or private research centers.
L'archive ouverte pluridisciplinaire HAL, est destinée au dépôt et à la diffusion de documents scientifiques de niveau recherche, publiés ou non, émanant des établissements d'enseignement et de recherche français ou étrangers, des laboratoires publics ou privés. 


\section{Fleur-de-lys abdominal body contouring surgery following massive weight loss.}

Yanis Berkane $\mathrm{MD}^{1}$, François Saget, $\mathrm{MD}^{1}$, Silvia Gandolfi, $\mathrm{MD}^{4}$, Théodoros Chrelias $\mathrm{MD}^{1}$, Eric Watier, $\mathrm{MD}, \mathrm{PhD}^{1,2,3}$, Nicolas Bertheuil, $\mathrm{MD}, \mathrm{PhD}^{1,2,3}$.

1 - Department of Plastic, Reconstructive and Aesthetic Surgery, Hospital Sud, University of Rennes 1, Rennes, France.

2 - INSERM U1236, University of Rennes 1, Rennes, France.

3 - SITI Laboratory, Rennes University Hospital, Rennes, France.

4 - Department of Plastic, Reconstructive and Aesthetic Surgery, CHU Rouen, Rouen, France. 
We read with great interest the manuscript entitled "Safety of fleur-de-lys abdominoplasty after massive weight loss" by DeSerres et al. ${ }^{1}$ We would like to congratulate the authors on their work on the abdominal sequelae of massive weight loss (MWL) patients exhibiting excess tissue and skin laxity in both the transverse and vertical dimensions. Unlike the fleur-de-lys (FDL) procedure, traditional abdominoplasty does not correct deformities that extend to both axes, as highlighted by the authors. We would like to discuss certain points that the authors raise, based on our experience and previous research. These may aid future studies.

First, in MWL patients, skin laxity and tissue excess are indeed evident in both the transverse and vertical abdominal axes, but these are also circular in nature. Thus, a circumferential reconstruction is usually necessary; lower bodylift procedures may be more appropriate than abdominoplasty.

Many studies have described the risk factors for complications after abdominoplasty. However, the complication rates of conventional and FDL abdominoplasty have not been compared; nor have those of the abdominoplasty and bodylift that are often offered to patients in need. We are not convinced that such interventions (i.e., FDL abdominoplasty/bodylift) increase the risk for major complications compared to traditional abdominoplasty. However, we observe that plastic surgeons remain reluctant to offer these longer interventions that are in fact better suited to correction of the deformities observed after MWL.

Second, between April 2018 and February 2021, we performed 11 FDL abdominoplasties and 21 FDL bodylifts (Table 1), as chosen by the patients, of whom $93 \%$ were female of mean age 46.8 years. The mean initial BMI was $30.4 \mathrm{~kg} / \mathrm{m}^{2}$ and the mean change in BMI was $18.1 \mathrm{~kg} / \mathrm{m}^{2}$. The overall complication rate was $28 \%$, broadly similar to that of the authors. We recorded one major complication (an infection) in the abdominoplasty group and eight minor complications (wound dehiscence) in the bodylift group. We found it notable that the two groups did not differ significantly in terms of preoperative data (overall $\mathrm{p}=0.416$; Table 2), particularly the BMI (29.5 vs. $\left.30.8 \mathrm{~kg} / \mathrm{m}^{2} ; \mathrm{p}=0.115\right)$. Older patients tended to choose the simpler and faster procedure; the abdominoplasty group was somewhat older than the bodylift group (50.5 vs. 44.9 years, $\mathrm{p}=0.258)$, although statistical significance was not attained. 
As also found by the authors, most complications were small dehiscences. However, we encountered no vertical and no "T-junction" dehiscence. This may reflect our surgical technique; we preoperatively mark the T-junction $2 \mathrm{~cm}$ under the umbilicus. In our opinion, this greatly reduces skin tension at the end of the procedure, and thus wound dehiscence.

Third, the authors found that the incidence of minor complications increased as more concurrent procedures were performed. This is in line with the findings of a recent review that compared abdominoplasty alone to both abdominoplasty and breast surgery; the complication rate was higher in the latter group. ${ }^{2}$ The valuable prospective study of Winocour, ${ }^{3}$ found that combined procedures increased the complication risk in multivariate analyses (relative risk $=1.5$ ).

In conclusion, we fully agree with the authors: FDL abdominoplasty is feasible and safe. Complications are not uncommon after abdominal, MWL, body-contouring reconstruction, but most are minor, easily managed in outpatient settings, and do not compromise either patient satisfaction or the quality of life. We thank the authors for their contribution to post-bariatric surgery reconstruction, and for improving our knowledge of factors predictive of postoperative complications. We believe that plastic surgeons must make greater efforts to help the complex subpopulation that requires reconstruction. 
ETHICAL STATEMENT

All clinical investigations adhered to all relevant tenets of the Declaration of Helsinki and were approved by our Committee for the Protection of Persons (CPP).

\section{DISCLOSURE}

No author has no financial interest to declare. No specific funding was received in the context of this communication.

\section{REFERENCES}

1. DeSerres J, Quaife T, Morzycki A, Curran M, Toy J. Safety of fleur-de-lis abdominoplasty after massive weight loss. J Plast, Reconstr \& Aesth Surg. 2021 Jan; 74(1) Pages 223-243.

2. Michot A, Alet JM, Pélissier P, Grolleau-Raoux JL, Bodin F, Chaput B. Morbidity in combinedprocedure associating abdominoplasty and breast surgery: A systematic review. Ann Chir Plast Esthet. 2015 doi: 10.1016/j.anplas.2015.07.009.

3. Winocour J, Gupta V, Ramirez JR, Shack RB, Grotting JC, Higdon KK. Abdominoplasty: Risk factors, complication rates, and safety of combined procedures. Plast Reconstr Surg. 2015 Nov;136(5):597e-606e. 
Table 1. Characteristics of the 32 patients

\begin{tabular}{|c|c|c|}
\hline Variable & Value & Range (min, max) \\
\hline Age, yr & 46.8 & $(24,6)$ \\
\hline Female sex, n (\%) & $30(63 \%)$ & - \\
\hline Abdominoplasty, n (\%) & $11(34 \%)$ & - \\
\hline Bodylift, n (\%) & $21(66 \%)$ & - \\
\hline Weight before MWL, kg & 130.3 & $(78,199)$ \\
\hline Weight before surgery, $\mathrm{kg}$ & 81.6 & $(57,116)$ \\
\hline Weight loss, kg & 48.4 & $(0,101)$ \\
\hline Percentage of weight loss (\%) & $35 \%$ & $(0 \%, 53 \%)$ \\
\hline Pre-MWL BMI, kg/m² & 48.4 & $(26.7,75.8)$ \\
\hline Pre-surgical BMI, kg/m² & 30.4 & $(21.5,43.8)$ \\
\hline \multicolumn{3}{|l|}{ ASA Score, $\mathrm{n}(\%)$} \\
\hline 1 & $3(10 \%)$ & - \\
\hline 2 & $26(81 \%)$ & - \\
\hline 3 & $3(10 \%)$ & - \\
\hline Operative time, min & 159.7 & 6 \\
\hline History of bariatric surgery, $\mathrm{n}(\%)$ & $29(90 \%)$ & \\
\hline Complications, n (\%) & $9(28 \%)$ & \\
\hline
\end{tabular}


Table 2. Statistical analysis

\begin{tabular}{lccc}
\hline & FDL abdominoplasty & FDL bodylift & $\mathrm{p}$ \\
\hline $\mathrm{n}$ & 11 & 21 & \\
Age $($ mean \pm SD) & $50.5 \pm 11$ & $44.9 \pm 11.5$ & $0.258^{*}$ \\
BMI (mean \pm SD) & $29.5 \pm 2.9$ & $30.8 \pm 5.8$ & $0.416^{*}$ \\
& & & \\
Complications (n; \%) & $1(9 \%)$ & $8(38 \%)$ & $0.115^{* *}$ \\
\hline
\end{tabular}

* Non parametric Mann-Whitney test ** Fisher's exact test 